William Joseph Thomas, Assistant Director for Collections and Scholarly Communications,

Joyner Library, East Carolina University

\title{
From "The Lost Colony" to "Unto These Hills": Outdoor Theatre in North Carolina
}

S ummertime is high season for outdoor dramas, and North Carolina has a rich history of them. Many NC natives have attended a production of "The Lost Colony" in Manteo or "Unto These Hills" in Cherokee. Other outdoor dramas in our state include "Strike at the Wind," in Pembroke; "Horn in the West," in Boone; "Tom Dooley: A Wilkes County Legend," in Wilkesboro; "First for Freedom," in Halifax; and "From this Day Forward," in Valdese. Shakespeare has his place in North Carolina too, from Asheville's Montford Park Players to Wilmington's Cape Fear Shakespeare.

The first, and arguably best-known, of North Carolina's outdoor dramas is "The Lost Colony." Written by $\mathrm{Pu}$ litzer prize-winning NC native Paul Green to commemorate its $350^{\text {th }}$ anniversary, "The Lost Colony" tells the story of the intended settlement of 1587 and subsequent disappearance of the 117 English colonists, including Virginia Dare, first English child born in the New World. ${ }^{1}$ Opening night was July 4, 1937, in the Waterside Theatre built by local Civilian Conservation Corps workers. ${ }^{2}$ Since a successful opening season, marked by the attendance of President Roosevelt on August 18 ${ }^{\text {th }}$, "The Lost

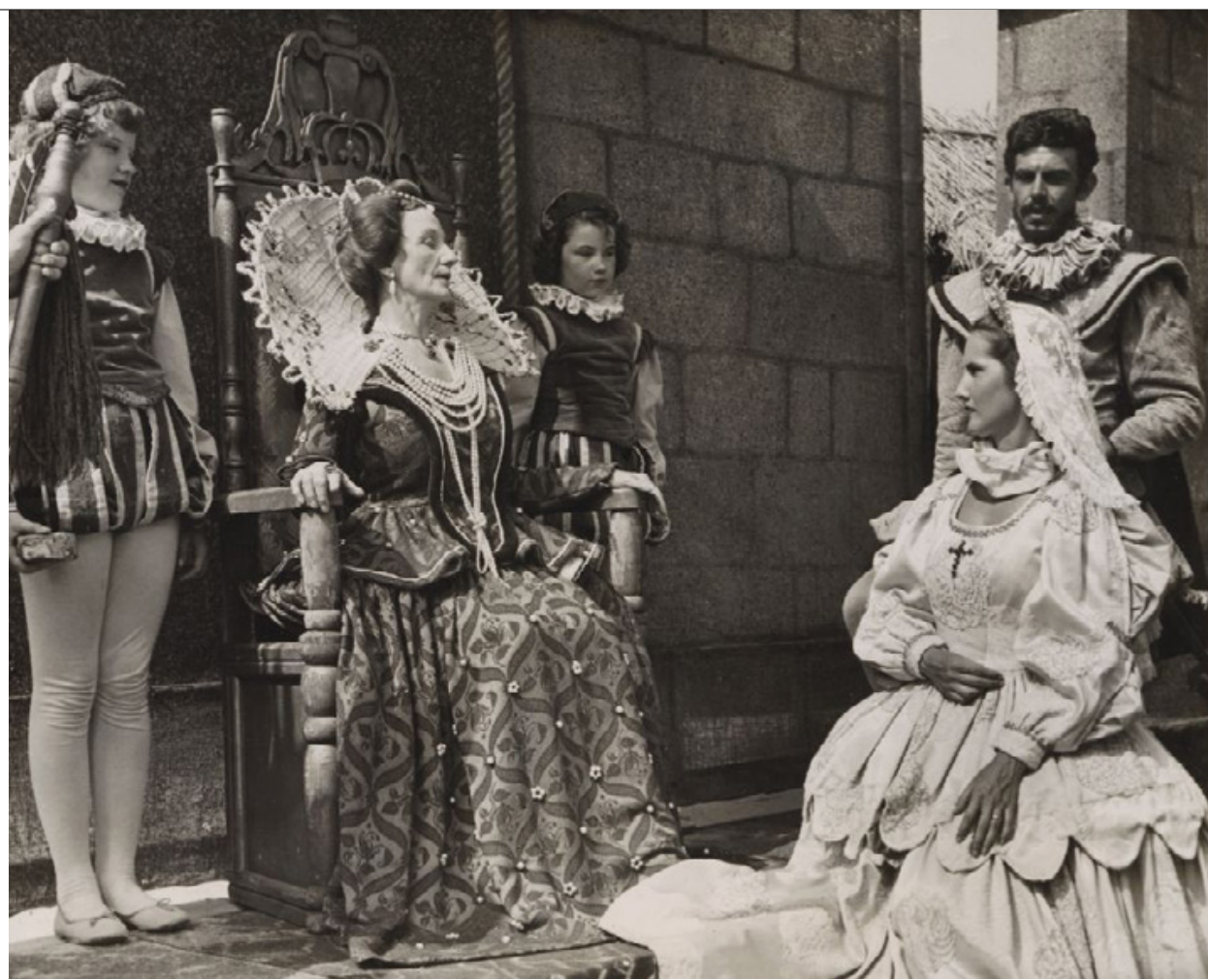

Figure 1: Andy Griffith in the The Lost Colony, 1950, from Joyner Library Digital Collections, http://digital.lib.ecu.edu/34133.

Colony" has entertained millions of audience members and provided opportunity for some 5,000 actors, including favorite North Carolina son Andy Griffith. The production is still going strong, now in its $82^{\text {nd }}$ season in Manteo.

"Strike at the Wind" tells the story of the legendary Lumbee Henry Berry Lowry and his "gang" of outlaws who evaded capture in swampy land around Robeson County from 1864 to $1872 .{ }^{3}$ Written by NCCU professor of drama Randolph Umberger, "Strike at the Wind" was performed at the Lakeside Amphitheatre near Pembroke from its opening on July 1,1976 , to 1996 , and revived from 1999 to 2007. Production had a 10 -year hiatus before being adapted for indoor performance in 2017 at the Givens Performing Arts Center,

1. Roanoke Island Historical Association. "The Lost Colony - A History of Making History." The Lost Colony. https://www.thelostcolony.org/the-lostcolony/.

2. Williams, Ashley. “Outdoor Theatre and the New Deal, Take Two.” Bringing the Outdoors 'Indoors': Processing the Institute of Outdoor Theatre's Archives. https://web.archive.org/web/20170707184426/http://blog.ecu.edu/sites/outdoortheatre/.

3. Oakley, Christopher Arris. The Legend of Henry Berry Lowry: Strike at the Wind and the Lumbee Indians of North Carolina. Mississippi Quarterly 60, no. 1 (2006): 59-80 


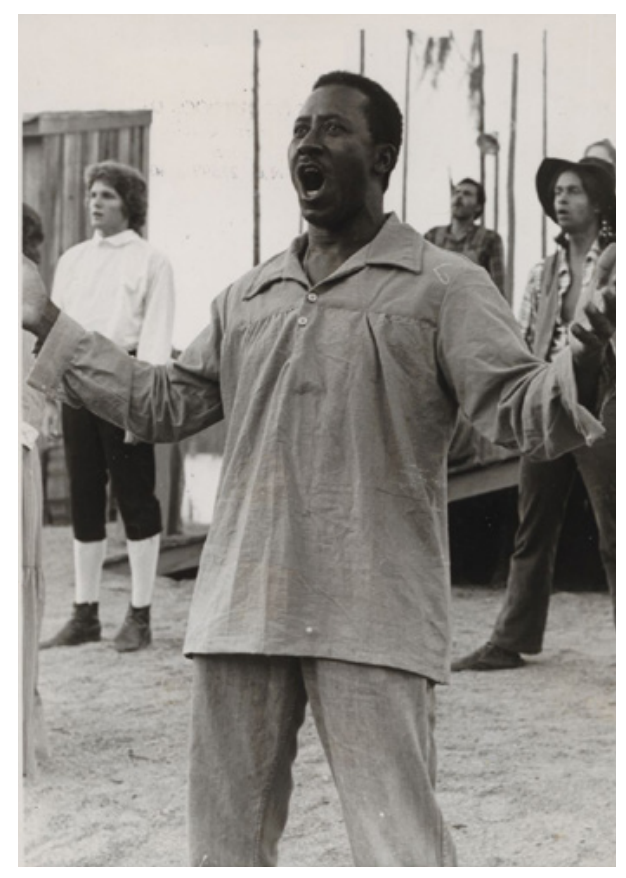

Figure 2: "Strike at the Wind" photo from Joyner Library Digital Collections, http://digital.lib. ecu.edu/37046.

and is, in July 2019, returning to the outdoors, with performances scheduled for the Adolph Dial Amphitheatre at the Lumbee Tribe Cultural Center. ${ }^{4}$ For the intriguing story of "Strike at the Wind" and its initial production and reception, see Christopher Oakley's "The Legend of Henry Berry Lowry: Strike at the Wind and the Lumbee Indians of North Carolina."

"Unto These Hills," the second-longest running outdoor drama in the US, was first staged July 1, 1950, at the Mountainside Theater in Cherokee. "Unto These Hills" was sponsored by the Cherokee Historical Association, with help in the planning and production by Samuel Selden of UNC Chapel Hill's Department of Dramatic Arts. Written by UNC

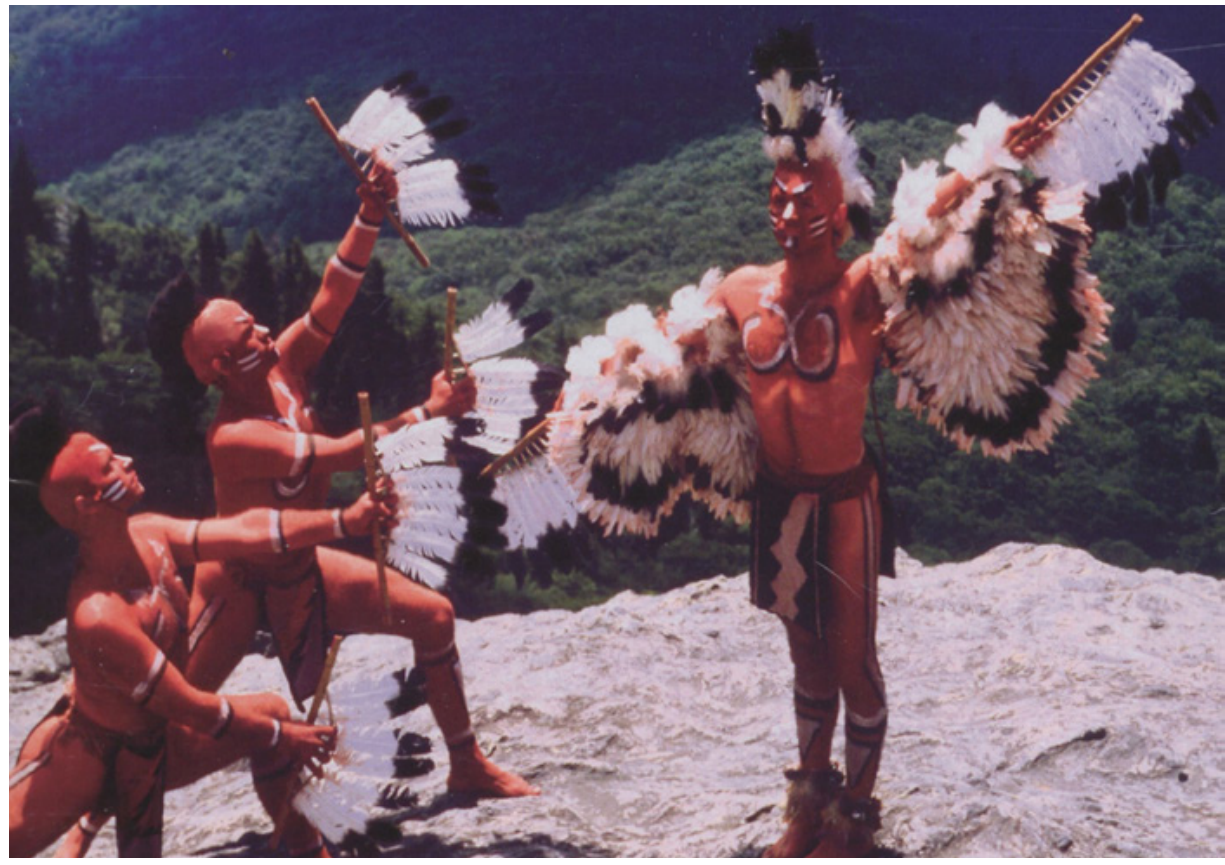

Figure 3: Detail from "Unto These Hills" Souvenir Program, 2005, from Joyner Library Digital Collections, http://digital.lib.ecu.edu/36971.

doctoral student Kermit Hunter, who also wrote "Horn in the West," among other plays, "Unto These Hills" traces the outline of Cherokee history from their interaction with de Soto in the 1540 s to Removal in the 1830 s. The original version of the play ends with Tsali's self-sacrifice that enabled the Eastern Band to remain in the North Carolina mountains. ${ }^{5}$ Beginning in the late 1990s, the script was revised several times to correct historical inaccuracies, including 2007, by Linda Swimmer, a tribal member who is also part of the Cherokee Historical Association. ${ }^{6}$ Recently a decision was made to return to a modified version of Hunter's original script. That revised version of Hunter's original play is now in production for the summer of $2019 .^{7}$
Support for these and other outdoor theatre productions in our state was provided by The Institute of Outdoor Theatre (IOT). The IOT has provided research, education, and advocacy for outdoor dramas, not just in North Carolina, since its founding in 1963 in Chapel Hill as the Institute of Outdoor Drama. Many of the playwrights, producers, and others involved in "The Lost Colony," "Strike at the Wind," "Unto These Hills," "Horn in the West," and other notable North Carolina outdoor dramas were part of the Institute of Outdoor Drama, UNC Chapel Hill's Department of Dramatic Arts, or the associated Carolina Playmakers (later Playmakers Repertory Company)_Paul Green, Samuel Selden, Kermit Hunter, and Randolph Umberger, among

\footnotetext{
4. “'Strike at the Wind!' Returns to Amphiteatre for a Sold-Out Show.” The Robesonian, July 8, 2019, sec. Features. https://www.robesonian.com/features/124921/strike-at-the-wind-returns-to-adolph-dial-amphitheater.

5. Moore, Cecelia. "Outdoor Dramas." NCPedia. 2006. https://www.ncpedia.org/outdoor-dramas.

6. Smithers, Gregory D. "A Cherokee Epic: Kermit Hunter's Unto These Hills and the Mythologizing of Cherokee History." Native South 8 (2015): 1-30.

7. "'Unto These Hills' Outdoor Drama." Cherokee North Carolina. http://visitcherokeenc.com/play/attractions/unto-these-hills-outdoor-drama/.

8. Department of Dramatic Art of the University of North Carolina at Chapel Hill Records \#40080, University Archives, Wilson Library, University of North Carolina at Chapel Hill.
} 
others. More details and some records related to the Institute of Outdoor Drama are available in the records of the Department of Dramatic Arts for UNC Chapel Hill at Wilson Library. ${ }^{8}$ In 2010, the Institute was relocated to East Carolina University, and in 2014, Institute records were donated to ECU's Joyner Library. The Library received funding from the National Archives' National Historical Publications and Records Commission to process the collection and begin digitization. ${ }^{9}$ Records in the collection span some 600 outdoor theatres across multiple states, including some that began in the 1920s. The plays themselves portray a panoply of American heroes and villains, from Lewis \& Clark to Blackbeard, Billy the Kid to Johnny Appleseed. Material types in the collection include scripts, promotional materials, photographs, letters, and audio and video files on everything from reel-to-reel tapes to floppy disks. Nearly 1,500 items from the collection have now been digitized and are available online. Highlights of the digital materials include photographs of the construction of the Waterside and the Mountainside Theatre (homes of "The Lost Colony" and "Unto These Hills"), a brochure from the premier season of "Strike at the Wind," an audio recording of "Horn in the West," and a silent film about the Lost Colony.

There was another transition in store, though: the Institute for Outdoor Theatre came under the aegis of the Southeastern Theatre Conference in 2017, although it continues its service today. ${ }^{10}$

The Southeastern Theatre Conference remains committed to "maintaining and building upon services that have long been valued by the outdoor theatre community, including Summer and Outdoor Theatre Auditions, an annual national conference, year-round consulting, and online resources". ${ }^{11}$ The Institute of Outdoor Theatre maintains its own website, to connect interested people to theatres by state (and country), to link to their book on Outdoor Theatre Facilities and other publications, and to point researchers to the Institute's archives at Joyner Library. Researchers are welcome to Joyner Library to make use of the collections.

And get outside! Which outdoor theatre production will you see this summer?

9. Institute of Outdoor Theatre Archives (\#1250), East Carolina Manuscript Collection, J.Y. Joyner Library, East Carolina University, Greenville, North Carolina, USA.

10. Horth, Betsey. "Institute of Outdoor Theatre to Become Part of SETC." SETC News. July / August 2016. https://issuu.com/setc.org/docs/2016-julyaugust $/ 15$ ? $=3431256 / 35348833$.

11. "Outdoor Theatre." Southeastern Theatre Conference. https://www.setc.org/about/iot/.

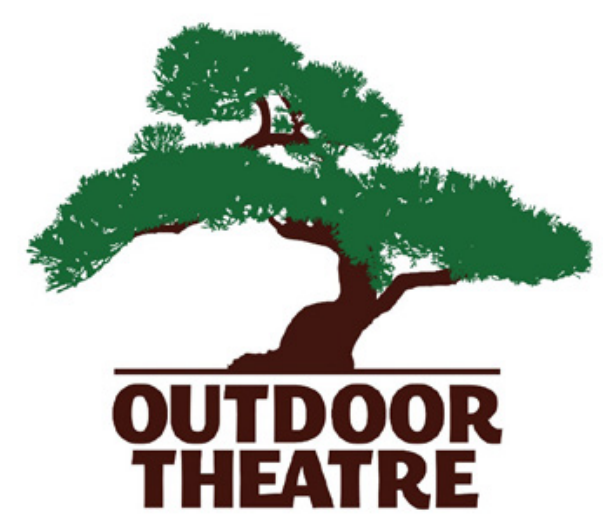

Figure 4: Institute of Outdoo Theatre Logo 